\title{
Effects of polymorphism of myostatin and fatty acid-binding protein 4 genes on the chemical composition of meat in cull female Aceh cattle
}

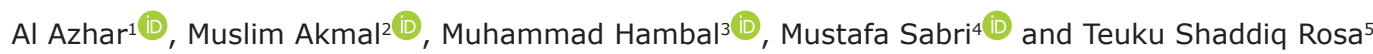

1. Department of Biochemistry, Faculty of Veterinary Medicine, Universitas Syiah Kuala, Banda Aceh, Aceh 23111, Indonesia; 2. Department of Histology, Faculty of Veterinary Medicine, Universitas Syiah Kuala, Banda Aceh, Aceh 23111, Indonesia; 3. Department of Parasitology, Faculty of Veterinary Medicine, Universitas Syiah Kuala, Banda Aceh, Aceh 23111, Indonesia; 4. Department of Anatomy, Faculty of Veterinary Medicine, Universitas Syiah Kuala, Banda Aceh, Aceh 23111, Indonesia; 5. Master Program of Veterinary Public Health, Faculty of Veterinary Medicine, Universitas Syiah Kuala, Banda Aceh, Aceh 23111, Indonesia.

Corresponding author: Al Azhar, e-mail: alazhar@unsyiah.ac.id

Co-authors: MA: akmal_kh@unsyiah.ac.id, MH: hambal.m@unsyiah.ac.id, MS: mustafa_sabriyosa@yahoo.com, TSR: teukushaddiq99@gmail.com

Received: 18-08-2019, Accepted: 14-05-2020, Published online: 14-07-2020

doi: www.doi.org/10.14202/vetworld.2020.1334-1343 How to cite this article: Azhar A, Akmal M, Hambal M, Sabri M, Rosa TS (2020) Effects of polymorphism of myostatin and fatty acid-binding protein 4 genes on the chemical composition of meat in cull female Aceh cattle, Veterinary World, 13(7): 1334-1343.

\begin{abstract}
Aim: This study aimed to investigate the association of single nucleotide polymorphism of the myostatin (MSTN) and fatty acid-binding protein 4 (FABP4) genes on the total water, ash, fat, protein, and cholesterol contents of sirloin (gluteus medius muscle) and silverside (biceps femoris muscle) meats of cull female Aceh cattle.

Materials and Methods: This analysis covered a total of 27 cull female Aceh cattle slaughtered at the Animal Slaughterhouse of Banda Aceh that was purposively selected based on hair color referred to the criteria described in the Decree of Ministry of Agriculture of the Republic of Indonesia. Genomic DNA was extracted from $25 \mathrm{mg}$ of fresh meat using the spin column method before subjected to a polymerase chain reaction amplification using primer sets specific for 1346-bp and 275bp fragments of MSTN and FABP4, respectively. A 4-h digestion reaction was done separately for the MSTN/HaeIII and FABP4/NlaIII loci genotyping. The total protein, ash, and fat of the meat were measured using the Indonesian National Standard (SNI) methods whereas its cholesterol content was determined using the AOAC method. The association between each polymorphism and the variation in meat chemical parameters was analyzed using the Pearson correlation test.
\end{abstract}

Results: The results showed that the MSTN/HaeIII locus was polymorphic in Aceh cattle, but the FABP4/NlaIII locus was monomorphic. Meat chemical parameters were not influenced by different commercial cuts and MSTN genotypes, showing that there was no association between different commercial cuts, cattle hair colors, and MSTN/HaeIII and FABP4/NlaIII markers with the meat chemical parameters in Aceh cattle.

Conclusion: These results suggest that focusing on the novel effects of MSTN and FABP4 gene polymorphisms on meat production traits might not be useful for marker-assisted selection in Aceh cattle.

Keywords: Aceh cattle meat, ash, cholesterol, fat, polymerase chain reaction-restriction fragment length polymorphism, protein.

\section{Introduction}

Interaction of one or more genetic polymorphisms with environmental factors is responsible for the inheritance of many economically desired traits of domesticated animals [1] such as higher production (dressing percentage, meat quality, and milk result) [2], reproduction [3], and disease resistance [4], as well as better adaptation to moisture, a hot tropical climate [5], low-quality food, and traditional farming [6]. These traits of economic importance, however, are not concurrently inherited in animals. Indigenous cattle, for example, are well known for good adaptation and low maintenance

Copyright: Azhar, et al. Open Access. This article is distributed under the terms of the Creative Commons Attribution 4.0 International License (http://creativecommons.org/licenses/by/4.0/), which permits unrestricted use, distribution, and reproduction in any medium, provided you give appropriate credit to the original author(s) and the source, provide a link to the Creative Commons license, and indicate if changes were made. The Creative Commons Public Domain Dedication waiver (http://creativecommons.org/ publicdomain/zero/1.0/) applies to the data made available in this article, unless otherwise stated. price, but have slow growth, delayed puberty, and low production compared to exotic cattle [7]. Slow growth, delayed puberty, and low production are traits generally attributed to Bos indicus (zebu) cattle [8]. The occurrence of the zebu genotype is also responsible for low meat tenderness [9] and texture [10], but higher fat content [11], three of the most important parameters of meat quality in the beef industry. Searching for the genetic basis of the desired phenotypic variations followed by integrating the data obtained in the currently used conventional breeding selection might shorten the selection process of Indonesian beef cattle.

Several genetic factors have been identified to be associated with varying meat nutritional quality trait. Among them, myostatin (MSTN) and fatty acid-binding protein 4 (FABP4) genes are the most interesting candidate factors. Inconsistent relationships may be found between these potential genetic markers and the meat quality of several cattle populations [12]. While some of the previously identified 20 polymorphisms (due to 
nucleotide deletion, insertion, or substitution) of MSTN are known to be linked to increased muscle $[13,14]$, polymorphisms found in either the exon or intron of FABP 4 have been shown to affect bovine backfat thickness [15], marbling, and carcass weight [16]. In Indonesia, unfortunately, there are limited information about meats chemical composition and nutritional value of local beef cattle. Furthermore, are not available scientific data about the potential genetic variations related to meat chemical and physical parameters. Although the diversity of exon-3 of MSTN has been studied in Indonesian Madura cattle[17], a previous study by Nugroho et al. [18] in Bali cattle is the only one that shows positive effects of MSTN polymorphism on the chest girth, weaning weight, and chest circumference.

At present, no research has addressed the effect of single polymorphism of MSTN and FABP4 on meat chemical parameters in Aceh cattle, a genetic resource of Indonesian beef cattle native to Aceh Province which originated from the cross-breeding of Indonesian local cattle (Bos sondaicus), Java cattle (Bos javanicus), and zebu cattle (Bos indicus) [19,20]. Naturally Aceh cattle have different hair colors, but only Aceh cattle have brick red hair color which fulfills the criteria mentioned in the Indonesian National Standard. We hypothesized the MSTN and FABP4 polymorphisms, different commercial cuts, and cattle hair colors might have some effects on meat chemical parameters and the physical quality of Aceh cattle, but there is no scientific information to prove this assumption.

Therefore, this study aimed to investigate the effect of MSTN and FABP4 polymorphisms on the chemical parameters of sirloin (gluteus medius [GM] muscle) and silverside (biceps femoris [BF] muscle) meats of Aceh cattle with different hair colors. Information obtained might provide a scientific basis for setting Aceh cattle with brick red hair color as the Indonesian National Standard criteria and might have some benefits to the existing cattle breeding selection programs in Indonesia.

\section{Materials and Methods}

\section{Ethical approval}

All protocols used in this study have been approved by the Faculty of Veterinary Medicine Committee of Animal Ethics, Universitas Syiah Kuala, Banda Aceh (Ref: 28/KEPH/II/2018).

\section{Samples collection}

This study was conducted from May 2018 to March 2019. Fresh sirloin (GM muscle) and silverside (BF muscle) meats, $250 \mathrm{~g}$ each, of 27 cull female Aceh cattle aged 8-12 years old with different hair colors (three light brown, three red brown/brick red, five grayish black, four black, six straight yellow, three grayish yellow, and three white) were purposively purchased from the Animal Slaughterhouse of Banda Aceh. This was to accommodate the naturally existing hair color variations among Aceh cattle herds as mentioned in the Decree of the Ministry of Agriculture of the Republic Indonesia Number 54/Permentan/OT.140/10/2006. The meats were kept cool $\left(4^{\circ} \mathrm{C}\right)$, brought to the Faculty of Veterinary Medicine Laboratory of Research at Universitas Syiah Kuala, and stored at $-20^{\circ} \mathrm{C}$ before examination. Molecular characterizations were performed on 27 sirloin meat samples collected and chemical analysis was performed on 40 ( 20 sirloin and 20 silverside) out of 54 meat samples due to limited research funding.

\section{Meat chemical analysis}

Using the commercial service at the Center for Agro-based Industry of Bogor, the total water, ash, fat, and protein contents of the meat samples were determined using the Indonesian National Standard (SNI) test methods of food and beverage [21], whereas meat cholesterol content was measured using the AOAC method [22]. Meat moisture was analyzed using the SNI protocol No. 01-2891-1992 point 5.1 (oven method). Here, 1-2 mg of meat sample was put in a pre-weighed closed bottle, and dried in an oven $\left(105^{\circ} \mathrm{C}\right)$ for $3 \mathrm{~h}$. The sample was cooled and reweighed. The procedure was repeated until a constant weight was achieved. Water content was quantified as a percentage of the sample mass [21].

The SNI method No. 01-2891-1992 point 6.1 (dry method) was used to determine meat ash content. Briefly, a porcelain cup was pre-conditioned in a furnace at an ashing temperature of $550^{\circ} \mathrm{C}$ for $30 \mathrm{~min}$, cooled at room temperature, and weighed. Meat samples, 1-2 g, were individually weighed using this porcelain cup, placed in a furnace, and dried to charcoal before an ashing step at $550^{\circ} \mathrm{C}$. The porcelain cup containing ash was cooled to room temperature in a desiccator and weighed. Total ash content was quantified as a percentage of the sample mass [21].

Meat protein content was measured using the SNI method No 01-2891-1992 point 7.1 (Kjeldahl method). Here, $0.51 \mathrm{~g}$ of meat sample was combined with $2 \mathrm{~g}$ of selenium and $25 \mathrm{~mL}$ of concentrated $\mathrm{H}_{2} \mathrm{SO}_{4}$, and heated for $2 \mathrm{~h}$. The mixture was cooled and diluted to $100 \mathrm{~mL}$ with distilled water. Five milliliters of aliquot mixture were mixed with $5 \mathrm{~mL}$ of $30 \%$ $\mathrm{NaOH}$ and 3-5 mL of phenolphthalein indicator and distillated for $10 \mathrm{~min}$ with $2 \%$ boric acid. The volume of $0.01 \mathrm{~N} \mathrm{HCl}$ solution used to neutralize distillate was measured to determine the nitrogen percentage. The protein content was calculated by multiplying the nitrogen percentage with 6.25 [21].

The Soxhlet method (SNI No. 01-2891-1992 point 8.2) was used to measure meat fat content. In brief, approximately 1-2 $\mathrm{g}$ of meat samples were put into a cotton-lined paper sleeve and dried for $1 \mathrm{~h}$ using an oven heated to $<80^{\circ} \mathrm{C}$. The dry meat was put into a Soxhlet apparatus connected with a fat jar containing a pre-weighed boiling stone. The fat was extracted using a hexane for $6 \mathrm{~h}$. After distilling the hexane, the extracted fat was dried in an oven $\left(105^{\circ} \mathrm{C}\right)$, cooled and weighed. Fat content was quantified as a percentage of the sample mass [20]. 
Meat cholesterol content was determined using gas chromatography according to the Association of Official Analytical Chemists (AOAC, USA) No. 994.10 [21]. Briefly, $2 \mathrm{~g}$ of fresh meat (W1) was saponified with $40 \mathrm{~mL}$ of $95 \%$ ethanol and $8 \mathrm{~mL}$ of $50 \%$ potassium hydroxide for approximately $70 \mathrm{~min}$ at $60^{\circ} \mathrm{C}$. The mixture was combined with $60 \mathrm{~mL}$ of $95 \%$ ethanol, incubated for $15 \mathrm{~min}$, and cooled in a closed flask at room temperature. The non-saponified fraction was extracted 3 times using $100 \mathrm{~mL}$ of toluene $\left(V_{l}\right)$, mixed with $110 \mathrm{~mL}$ of $1 \mathrm{M} \mathrm{KOH}$ by vigorous shaking for $10 \mathrm{~min}$, and incubated at room temperature to allow layers formation. The toluene layer was mixed with $40 \mathrm{~mL}$ of $0.5 \mathrm{M} \mathrm{KOH}$ and washed $\geq 3$ times with distilled water. The clear toluene layer formed was poured into a new $125 \mathrm{~mL}$ Erlenmeyer flask, added with $2 \mathrm{~g}$ of $\mathrm{Na}_{2} \mathrm{SO}_{4}$, and incubated at room temperature for $\geq 15 \mathrm{~min}$. The extract, $25 \mathrm{~mL}\left(V_{2}\right)$, was evaporated to dryness on a rotary evaporator at $40 \pm 3^{\circ} \mathrm{C}$, and mixed with $3 \mathrm{~mL}$ of acetone. After evaporating the extract to dryness again, the residue was dissolved in $3 \mathrm{~mL}$ of dimethylformamide $\left(V_{3}\right)$. Standard aliquots $(0.0025-0.2 \mathrm{mg} / \mathrm{mL}), 1 \mathrm{~mL}$ each, were mixed with $2.0 \mathrm{~mL}$ of hexamethyldisilane, incubated at room temperature for $15 \mathrm{~min}$, and then mixed with $1 \mathrm{~mL}$ of $5 \alpha$-cholesterol internal standard solution $(1 \mathrm{mg} / \mathrm{mL}$ in heptane). After centrifugation for $2 \mathrm{~min}$, the heptane layer was collected. Standards and test solutions, $1 \mu \mathrm{L}$ each, were injected to a gas chromatograph. Peak areas of $5 \alpha$-cholestane and cholesterol were determined using height-weight measurements. Standard response ratio was calculated by dividing cholesterol peak area by internal standard peak area. The ratio response of the four highest standards was plotted against cholesterol concentrations. The amount of meat sample portion per milliliter (in grams) was determined by multiplying the ratio of meat sample examined and the volume of toluene used with the ratio of aliquot taken to dryness and the volume of dimethylformamide used to solve residue $\left(W_{1} / V_{1} \times W_{2} / V_{2}\right)$. Meat cholesterol content (mg) was determined by dividing the amount of cholesterol in the meat sample examined based on a standard curve by the amount of sample portion per milliliter [22].

\section{DNA extraction}

Genomic DNA was isolated from each sirloin meat sample at room temperature using a PureLink ${ }^{\mathrm{TM}}$ Genomic DNA Mini Kit (Invitrogen Life Technologies, USA) following protocol provided by the manufacturer. In brief, 20-25 mg of fresh meats were minced, immersed in digestion buffer mix, and incubated at $55^{\circ} \mathrm{C}$ for $2 \mathrm{~h}$ with occasional vortexing. After spinning for 3 min at 16,000× g, supernatant was mixed with $20 \mu \mathrm{L}$ of RNase A and incubated for $2 \mathrm{~min}$. The lysate was mixed with $200 \mu \mathrm{L}$ of genomic lysis/binding buffer, added with $200 \mu \mathrm{L}$ of absolute ethanol, and mixed by short vortexing. The entire mixture was transferred to a spin column in a collection tube and spun at $1000 \times \mathrm{g}$ for $1 \mathrm{~min}$. After replacing the collection tube, $500 \mu \mathrm{L}$ of wash buffer- 1 was added, and the column was respun at $10,000 \times \mathrm{g}$ for $1 \mathrm{~min}$. This washing step was repeated using wash buffer- 2 and 3-min spinning at $16,000 \times$ g. Genomic DNA was eluted from the spin column by 1 min incubation with $50 \mu \mathrm{L}$ of elution buffers followed by spinning at $16,000 \times \mathrm{g}$ for $1 \mathrm{~min}$. The quality of DNA extract was checked by electrophoresis on a $1 \%$ agarose/ $1 \times \mathrm{TAE}$ gel stained with a $\mathrm{SYBR}^{\mathrm{TM}}$ Safe (Invitrogen Life Technologies, USA) stain using a 100 -bp ladder as a molecular size marker, and visualized using a digital imaging system (Bio-Rad, USA). Purified DNA extract was stored at $-20^{\circ} \mathrm{C}$ [23].

\section{Genotyping}

Polymorphism of MSTN and FABP4 was examined with the polymerase chain reaction-restriction fragment length polymorphism (PCR-RFLP) approach. Primer sequences, PCR conditions and restriction enzymes used are presented in Table-1 $[16,18,24]$. The PCR reaction mixture $(25 \mu \mathrm{L})$ was prepared by adding 3 $\mu \mathrm{L}$ of template DNA (5-10 pg), 12.5 $\mu \mathrm{L}$ of PCR-master mix (Invitrogen Life Technologies, USA), forward and reverse primers ( $1 \mu \mathrm{L}$ each), and $7.5 \mu \mathrm{L}$ of nuclease-free water. The DNA amplification was done in a Bio-Rad (USA) thermal cycler. After amplification, $5 \mu \mathrm{L}$ of PCR products were added with 15 units of the corresponding restriction enzyme, and incubated at $37^{\circ} \mathrm{C}$ for $4 \mathrm{~h}$. The digestion products were analyzed by electrophoresis on $1.5 \%$ agarose $/ 1 \times \mathrm{TAE}$ gel (Invitrogen Life Technologies, USA) stained with a SYBR ${ }^{\text {TM }}$ Safe stain using a 100-bp ladder as molecular size marker. The electrophoresis was run at $80 \mathrm{~V}$ for $1.5 \mathrm{~h}$ and visualized using a digital imaging system (Bio-Rad, USA) [23].

\section{Statistical analysis}

Based on the DNA pattern, genetic polymorphism was tested using the formula: $\mathrm{PiCi}=1-\Sigma \mathrm{p} 2 \mathrm{ij}$. $\mathrm{PiCi}$ is the polymorphic information contained for the $\mathrm{i}^{\text {th }}$ locus and $\mathrm{pij}$ is frequency of the $\mathrm{j}^{\text {th }}$ allele for the $\mathrm{i}^{\text {th }}$ locus. A Chi-square test was used to determine the agreement of allele distribution to the Hardy-Weinberg equilibrium. Data allele and genotype frequencies were analyzed by SPSS software version 23 for Windows (IBM, USA). While difference in meat composition between different commercial cuts was

Table-1: Fragment size, PCR primers and conditions, and restriction enzymes used in the analysis of MSTN and FABP4 polymorphisms.

\begin{tabular}{|c|c|c|c|c|c|}
\hline Gene & $\begin{array}{l}\text { Fragment } \\
\text { size (bp) }\end{array}$ & PCR primers $\left(5^{\prime}\right.$ to $\left.3^{\prime}\right)$ & PCR conditions & $\begin{array}{l}\text { Restriction } \\
\text { enzyme }\end{array}$ & Reference \\
\hline MSTN & 1,346 & $\begin{array}{l}\text { F: 5'CCCTACAGAGGCCACTTCAA3' } \\
\text { R: 5'CTCGCTGTTCTCATTCAGATC3' }\end{array}$ & $\begin{array}{l}94^{\circ} \mathrm{C} 3^{\prime},\left(94^{\circ} \mathrm{C} 3 \mathrm{~s}, 63^{\circ} \mathrm{C} 30 \mathrm{~s},\right. \\
\left.72^{\circ} \mathrm{C} 1^{\prime}\right) 39 \text { cycles, } 72^{\circ} \mathrm{C} 10^{\prime}\end{array}$ & HaeIII & $\begin{array}{l}{[24]} \\
{[18]}\end{array}$ \\
\hline FABP4 & 565 & $\begin{array}{l}\text { F: 5'ACCCCTATGATGCTATTCCACA3' } \\
\text { R: 5'ATACGGTTCACATTGAGAGGGA3' }\end{array}$ & $\begin{array}{c}95^{\circ} \mathrm{C} 4^{\prime},\left(94^{\circ} \mathrm{C} 1^{\prime}, 60^{\circ} \mathrm{C} 1^{\prime}, 72^{\circ} \mathrm{C}\right. \\
\left.1.5 \mathrm{~min}^{-1}\right) 35 \mathrm{cycles}^{\circ} 72^{\circ} \mathrm{C} 5^{\prime}\end{array}$ & NlaIII & {$[16]$} \\
\hline
\end{tabular}


determined using a one-way ANOVA, the relationship between meat chemical parameters and gene polymorphism was analyzed using Pearson's correlation test.

\section{Results}

\section{Meat chemical composition}

The meat chemical parameters in the two commercial cuts of the cattle analyzed were comprised of water, ash, protein, fat, and cholesterol, as presented in Table-2. Silverside meats of Aceh cattle tended to have higher moisture, ash, protein, and cholesterol contents than sirloin meats. Sirloin meats, on the other hand, slightly contained more fat than silverside meats. The differences in meat chemical parameters observed, however, were not significant ( $\mathrm{p}>0.05)$.

Meat chemical parameters of Aceh cattle with different hair colors are listed in Table-3. The water, ash, protein, fat, and cholesterol contents in the meats of Aceh cattle with black hair were not significantly different from Aceh cattle with grayish black hair, straight yellow hair, white hair, and brick red hair.

\section{Polymorphism of MSTN and FABP4 and meat chemi-} cal composition

The results from PCR-RFLP experiment using the HaeIII restriction enzyme on 27 sirloin meat samples revealed that the MSTN is polymorphic in Aceh cattle as shown by the occurrence of $\mathrm{AA}, \mathrm{AB}$, and $\mathrm{BB}$ genotypes in the population [23]. The FABP4, on the other hand, is monomorphic in Aceh cattle by the presence of a single uncut AA genotype. The results of PCR-RFLP of MSTN and FABP4 fragments from several samples are presented in Figure-1 and 2 [23], respectively.

Table-2: Meat chemical parameters ( \pm SD) of two commercial cuts of Aceh cattle.

\begin{tabular}{lccc}
\hline Chemical parameters & \multicolumn{2}{c}{ Commercial cut } & \multirow{2}{*}{ Average } \\
\cline { 2 - 3 } & Sirloin & Silverside & $70.57 \pm 4.66$ \\
\hline Water (\%) & $69.65 \pm 4.60^{\mathrm{ns}}$ & $71.50 \pm 4.64^{\mathrm{ns}}$ & $0.96 \pm 0.09$ \\
Ash $(\%)$ & $0.96 \pm 0.09^{\mathrm{ns}}$ & $0.97 \pm 0.10^{\mathrm{ns}}$ & $17.20 \pm 2.62$ \\
Protein $(\mathrm{N} \times 6.25 \%)$ & $16.93 \pm 2.56^{\mathrm{ns}}$ & $17.48 \pm 2.72^{\mathrm{ns}}$ & $3.07 \pm 2.40$ \\
Fat $(\%)$ & $3.62 \pm 2.87^{\mathrm{ns}}$ & $2.52 \pm 1.71^{\mathrm{ns}}$ & $71.90 \pm 22.96$ \\
Cholesterol $(\%)$ & $71.62 \pm 17.03^{\mathrm{ns}}$ & $72.18 \pm 28.14^{\mathrm{ns}}$ & \\
\hline
\end{tabular}

$\mathrm{ns}=$ differences presented in the same row were not significant

Table-3: Meat chemical parameters ( \pm SD) of Aceh cattle with different hair colors.

\begin{tabular}{|c|c|c|c|c|c|}
\hline \multirow[t]{2}{*}{ Chemical parameters } & \multicolumn{5}{|c|}{ Cattle hair color } \\
\hline & Black & Grayish black & Straight yellow & White & Brick red \\
\hline \multicolumn{6}{|l|}{ Water (\%) } \\
\hline Sirloin & $69.40 \pm 6.45^{\mathrm{ns}}$ & $67.63 \pm 5.57^{\mathrm{ns}}$ & $70.57 \pm 5.28^{\mathrm{ns}}$ & $69.73 \pm 0.51^{\mathrm{ns}}$ & $70.43 \pm 4.55^{\mathrm{ns}}$ \\
\hline Silverside & $70.90 \pm 6.20^{\mathrm{ns}}$ & $68.93 \pm 5.45^{\mathrm{ns}}$ & $72.00 \pm 4.36^{\mathrm{ns}}$ & $72.97 \pm 4.69^{\mathrm{ns}}$ & $72.65 \pm 4.61^{\mathrm{ns}}$ \\
\hline \multicolumn{6}{|l|}{ Ash (\%) } \\
\hline Sirloin & $0.96 \pm 0.16^{\mathrm{ns}}$ & $0.96 \pm 0.04^{\mathrm{ns}}$ & $0.96 \pm 0.07^{\mathrm{ns}}$ & $0.95 \pm 0.16^{\mathrm{ns}}$ & $0.97 \pm 0.11^{\mathrm{ns}}$ \\
\hline Silverside & $0.87 \pm 0.10^{\mathrm{ns}}$ & $0.95 \pm 0.06^{\mathrm{ns}}$ & $0.99 \pm 0.09^{n s}$ & $0.99 \pm 0.11^{\mathrm{ns}}$ & $1.00 \pm 0.11^{\mathrm{ns}}$ \\
\hline \multicolumn{6}{|l|}{ Protein (\%) } \\
\hline Sirloin & $16.87 \pm 4.60^{\mathrm{ns}}$ & $17.28 \pm 1.15^{\mathrm{ns}}$ & $17.05 \pm 2.14^{\mathrm{ns}}$ & $16.03 \pm 3.54^{\mathrm{ns}}$ & $17.13 \pm 2.98^{\mathrm{ns}}$ \\
\hline Silverside & $16.33 \pm 3.96^{\mathrm{ns}}$ & $18.10 \pm 2.05^{\mathrm{ns}}$ & $17.72 \pm 1.77^{\mathrm{ns}}$ & $16.33 \pm 4.68^{\mathrm{ns}}$ & $18.20 \pm 2.92^{\mathrm{ns}}$ \\
\hline \multicolumn{6}{|l|}{ Fat (\%) } \\
\hline Sirloin & $2.42 \pm 0.78^{\text {ns }}$ & $4.89 \pm 2.76^{\mathrm{ns}}$ & $4.89 \pm 4.32^{\mathrm{ns}}$ & $2.13 \pm 0.33^{\mathrm{ns}}$ & $2.44 \pm 1.44^{\mathrm{ns}}$ \\
\hline Silverside & $3.24 \pm 0.56^{\mathrm{ns}}$ & $4.36 \pm 2.81^{\mathrm{ns}}$ & $1.50 \pm 0.89^{\text {ns }}$ & $1.50 \pm 0.37^{\mathrm{ns}}$ & $2.42 \pm 0.97^{\mathrm{ns}}$ \\
\hline \multicolumn{6}{|l|}{ Cholesterol } \\
\hline Sirloin & $64.10 \pm 8.82^{\mathrm{ns}}$ & $79.38 \pm 21.57^{n s}$ & $75.75 \pm 19.89^{\text {ns }}$ & $65.37 \pm 22.65^{\text {ns }}$ & $67.98 \pm 9.53^{\mathrm{ns}}$ \\
\hline Silverside & $60.20 \pm 8.88^{\mathrm{ns}}$ & $69.53 \pm 20.51^{\mathrm{ns}}$ & $74.95 \pm 18.95^{\text {ns }}$ & $97.53 \pm 64.26^{\mathrm{ns}}$ & $60.63 \pm 14.24^{\mathrm{ns}}$ \\
\hline
\end{tabular}

$\mathrm{ns}=$ differences presented in the same row were not significant

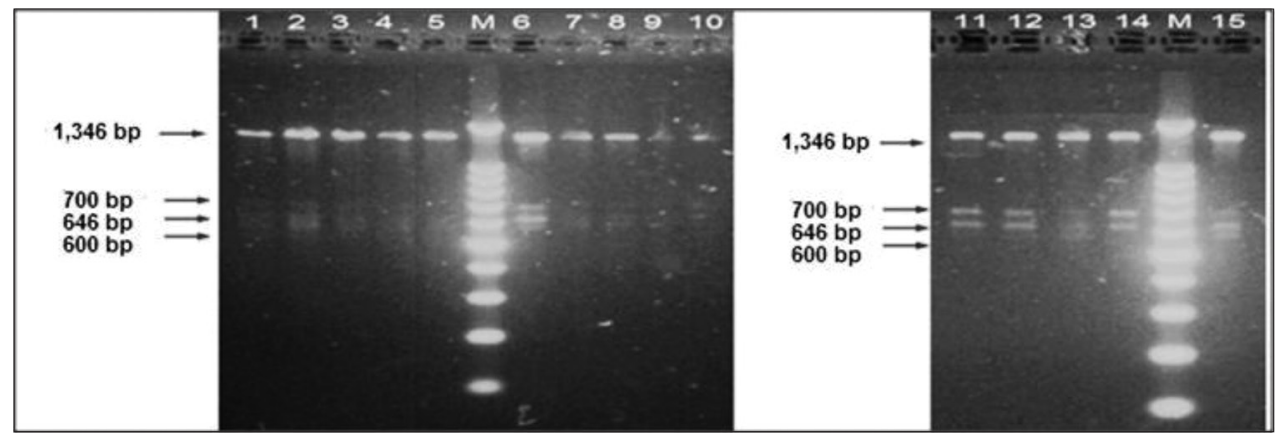

Figure-1: Results of agarose gel electrophoresis of myostatin reaction restriction fragment length polymorphism fragments (1346, 700, 646, and 600 bp). Lane M, 100 bp ladder. Lane 01-05, Aceh cattle examined [23]. 
As shown in Figure-1, the PCR-RFLP analysis using the HaeIII enzyme showed that the $1346 \mathrm{bp}$ MSTN fragment was cut into 700 and $646 \mathrm{bp}$ fragments (AA), 700, 646, 618, and $28 \mathrm{bp}$ fragments $(\mathrm{AB})$ or 618 and $28 \mathrm{bp}$ fragments (BB). With a polymorphism degree of 0.51 (Table-4) [23], the MSTN genotype distribution in the Aceh cattle population agreed well with the Hardy-Weinberg equilibrium $\left(\chi^{2}=0.55\right)$. The respective frequency of allele A and B was 0.45 and 0.55 .

The meat chemical parameters of Aceh cattle with different MSTN genotypes are presented in Table-5. The data showed that meat chemical parameters analyzed were not markedly different among the cattle carry certain MSTN genotypes, showing that the chemical parameters of Aceh cattle meat were not influenced by MSTN gene.

\section{Discussion}

Meat is a complex biological system made of water up to $75 \%$ that is in balance circumstance with

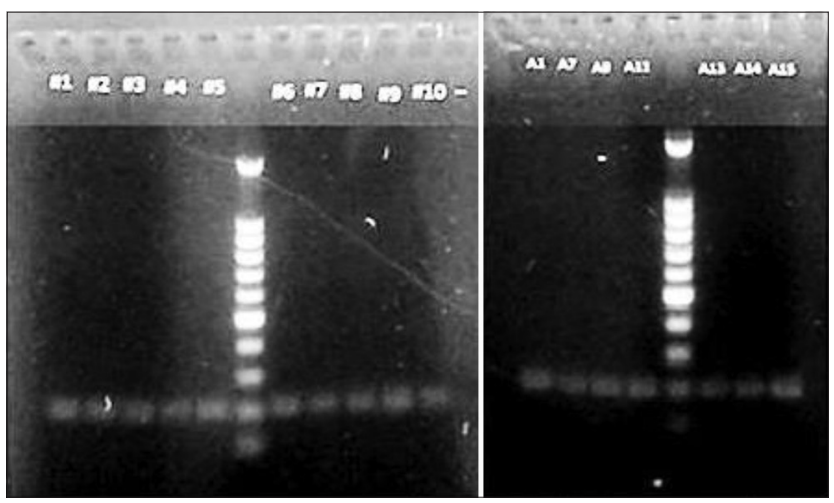

Figure-2: Results of agarose gel electrophoresis of FABP4 restriction fragment length polymorphism fragment (200 bp). Lane M, 100 bp ladder. Lane 01-15, Aceh cattle examined.
$20 \%$ protein, $2 \%$ fat, and $3 \%$ other small components such as minerals, phosphoric containing molecules, and vitamins [25]. Water, ash, protein, and fat contents of sirloin (GM muscle) and silverside (BF muscle) meats of female Aceh cull cattle obtained in this study (Table-2) were different from those reported in other cattle, either B. indicus or B. taurus. The moisture composition of sirloin and silverside meats of Aceh cattle, $69.12 \pm 4.50 \%$ and $69.95 \pm 3.76 \%$, respectively, is lower than that reported in Bali cattle meats (72.84 $\pm 0.79 \%$ ) [26], GM and Longissimus dorsi (LD) muscles of adult Limousin x Luxi crossbreed steers, $74.4 \%[27]$.

Comparing the meats from Bali (GM 1.13\%2.15\%) [24] and Limousin x Luxi crossbreed cattle (GM 1.77\% and LD 1.66\%) [27], the Aceh's meat contains, in the same muscles, less ash $1.00 \pm 0.06 \%$ and $1.00 \pm 0.06 \%$ (GM and LD, respectively). While the protein content of the Aceh cattle meats (GM muscle $17.76 \pm 1.73 \%$ and $\mathrm{BF}$ muscle $18.28 \pm 1.92 \%$ ) is in agreement with those reported by Buckle et al. [28], $16-22 \%$; they are lower than those found in Bali cattle meats, protein $21.64 \pm 1.08 \%$ [26] or GM and Ld muscles of adult male Limousin x Luxi crossbreed $(22.9 \%$ and $22.8 \%$, respectively) [27].

In addition to water, ash, and protein, the fat content of the sirloin and silverside meats of Aceh cattle found in this study, $3.53 \pm 2.64 \%$ and $2.77 \pm 1.81 \%$, respectively, were in agreement with the range reported in Aceh cattle, 3-6\% [29] and male Limousin x Luxi crossbreed (1.7\%) [27], but markedly lower than that found in Bali cattle, 13.82-19.05\% [26]. The cholesterol content of Aceh cattle meats, GM $76.59 \pm 14.78 \mathrm{mg} / 100 \mathrm{~g}$ and $\mathrm{BF} 72.69 \pm 13.23$ $\mathrm{mg} / 100 \mathrm{~g}$, was comparable to those reported in the semi membranosus and $\mathrm{BF}$ muscles of indigenous

Table-4: MSTN allele and genotype frequencies and polymorphism in Aceh cattle*.

\begin{tabular}{|c|c|c|c|c|c|}
\hline \multicolumn{2}{|c|}{ Total genotype } & \multicolumn{2}{|c|}{ Frequency } & \multirow[t]{2}{*}{ Polymorphism degree } & \multirow[t]{2}{*}{ Hardy-Weinberg Equilibrium ( $\chi^{2}$ test) } \\
\hline Observed & Expected & Genotype & Allele & & \\
\hline$A A=5$ & $\mathrm{AA}=4.1$ & $A A=0.18$ & $A=0.45$ & 0.51 & $\chi^{2}=0.55$ \\
\hline$A B=11$ & $A B=12.1$ & $A B=0.41$ & $B=0.55$ & & \\
\hline $\mathrm{BB}=11$ & $\mathrm{BB}=10.8$ & $\mathrm{BB}=0.41$ & & & \\
\hline
\end{tabular}

*Modified from Azhar et al. [23]

Table-5: Average meat chemical parameters of Aceh cattle with different MSTN genotypes.

\begin{tabular}{llccc}
\hline Meat chemical parameters & Commercial cut & \multicolumn{3}{c}{ MSTN genotype } \\
\cline { 3 - 5 } & & AA & AB & BB \\
\hline Water (\%) & Sirloin & $70.57 \pm 4.05^{\text {ns }}$ & $68.57 \pm 5.34^{\text {ns }}$ & $71.17 \pm 3.31^{\text {ns }}$ \\
& Silverside & $70.93 \pm 5.97^{\text {ns }}$ & $70.32 \pm 4.14^{\text {ns }}$ & $73.93 \pm 4.80^{\text {ns }}$ \\
Ash (\%) & Sirloin & $0.94 \pm 0.09^{\text {ns }}$ & $0.98 \pm 0.09^{\text {ns }}$ & $0.95 \pm 0.12^{\text {ns }}$ \\
Protein ( $\times 6.25 \%)$ & Silverside & $0.95 \pm 0.12^{\text {ns }}$ & $0.97 \pm 0.09^{\text {ns }}$ & $0.98 \pm 0.11^{\text {ns }}$ \\
& Sirloin & $18.13 \pm 0.31^{\text {ns }}$ & $17.10 \pm 2.56^{\text {ns }}$ & $16.02 \pm 3.12^{\text {ns }}$ \\
Fat $(\%)$ & Silverside & $18.13 \pm 1.72^{\text {ns }}$ & $17.51 \pm 2.72^{\text {ns }}$ & $17.07 \pm 3.41^{\text {ns }}$ \\
& Sirloin & $5.83 \pm 4.72^{\text {ns }}$ & $3.74 \pm 2.82^{\text {ns }}$ & $2.28 \pm 1.18^{\text {ns }}$ \\
Cholesterol $(\%)$ & Silverside & $2.26 \pm 2.25^{\text {ns }}$ & $3.09 \pm 1.86^{\text {ns }}$ & $1.59 \pm 0.65^{\text {ns }}$ \\
& Sirloin & $63.60 \pm 22.39^{\text {ns }}$ & $75.81 \pm 16.54^{\text {ns }}$ & $67.82 \pm 16.13^{\text {ns }}$ \\
& Silverside & $61.27 \pm 23.18^{\text {ns }}$ & $70.72 \pm 15.51^{\text {ns }}$ & $63.63 \pm 16.66^{\text {ns }}$ \\
\hline
\end{tabular}

$\mathrm{ns}=$ differences presented in the same row were not significant 
cattle in southern Brazil measured by enzymatic $(60.63 \pm 2.33 \mathrm{mg} / 100 \mathrm{~g}$ and $63.02 \pm 3.62 \mathrm{mg} / 100 \mathrm{~g}$, respectively) and HPLC $(51.97 \pm 1.40 \mathrm{mg} / 100 \mathrm{~g}$ and $63.44 \pm 3.75 \mathrm{mg} / 100 \mathrm{~g}$, respectively) methods [30]. No information is available about the cholesterol content of both Bali and Limousin x Luxi crossbreed cattle to make a comparison.

Khasrad et al. [31] reported that cattle breed significantly affected water, protein, and fat contents of the LD muscle of Bali, Pesisir, Simmental cross, and Brahman cross cattle. The average water content of meat in B. indicus $77.50 \pm 0.40 \%$ [32] is higher than that in B. taurus, $72.40-74.80 \%$ [31]. Evidence for the influence of breed on chemical content of meat is also shown by a higher percentage of meat ash of $B$. taurus compared to that of B. indicus [32].

The effect of cattle age on meat composition is not only shown by a decreased meat fat content according to age of the Bali cattle but also from the fact that the meat of young (2.0-2.5 years old) and old (7-10 years old) Bali cattle has significantly lower ash content than that of adult (3.5-6 years old) Bali cattle [26]. In addition, the effect of age on the profile of meat chemical parameters was also seen in 1- and 2-year-old Limousin x Luxi crossbreed cattle [27].

Data in Table-2 also show that the differences in protein, fat, and cholesterol contents between sirloin and silverside meats were not significant. This indicated that different commercial cuts did not have an obvious effect on the chemical composition of the meat of the Aceh cattle evaluated. This finding is different from that reported by Rhee et al. [33], who found that muscle types have a great effect on the chemical traits of beef meats when analyzed palatability and biochemical traits variation in 11 beef meats. Wang et al. [27] also found an effect of muscle types on the nutrient profile of Limousin x Luxi crossbreeds.

The occurrence of naturally different hair colors might have some benefits in Aceh cattle. The results of this study did not show the effect of hair color variations on chemical parameters of Aceh cattle (Table-3). Although chemical parameter differences were observed among Aceh cattle with different hair colors, they were not significant. Some factors that might contribute to these facts are that relatively high individual variations existed in some chemical parameters among the cattle and the small sample size. Further study must be done to confirm this prediction.

As one of the potential genes that influence the muscle growth and the depth of intramuscular fat in some cattle [13], it is possible that MSTN polymorphism affects the chemical composition of meat, a hypothesis that we wanted to analyze in this study. We found the polymorphic condition and balance distribution of MSTN in Aceh cattle, situations that are in agreement with the findings reported in Bali cattle by Nugroho et al. [18]. Dunner et al. [34] also reported a breed-specific haplotype in the MSTN of many European cattle breeds. The monomorphic condition of the MSTN genotype, on the other hand, was observed in several European [35,36], Indian [7], and native Turkish breed cattle [37]. The presence of three (AA, AB, and $\mathrm{BB}$ ) genotypes in Aceh cattle (this study) was different from the finding of Nugroho et al. [18] showing only AB and BB genotypes identified in Bali cattle.

The RFLP digestion using the HaeIII restriction enzyme on Aceh cattle MSTN performed in this study resulted in flank cut 1346-bp B fragment into 700, 646, 618, and 28 bp fragments. Nugroho et al. [18] interestingly found five fragments $90,100,250,450$, and $546 \mathrm{bp}$ fragments from the digestion of the 1346bp MSTN of Bali cattle amplified using the same primer set. These facts show that different numbers of restriction sites of HaeIII enzyme are available in MSTN between Bali and Aceh cattle.

To confirm the difference, MSTN amplified from one genomic DNA sample with $\mathrm{AB}$ genotype (its HaeIII digestion resulting in 700,646,618, and 28 bp fragments) was sent to PT Genetika Science Indonesia for a commercial sequencing service. Nucleotide sequences of Aceh cattle MSTN obtained from sequencing using forward and reverse primers were then individually analyzed using APE Software (University of Utah, Salt Lake City, UT). The results showed the absence of a HaeIII restriction site along the 556 nucleotide sequence product of Aceh cattle MSTN sequenced using forward primer. The 597 nucleotide sequence resulting from MSTN sequencing using a reverse primer, on the other hand, contained one HaeIII restriction site at the nucleotide position of 53 (Figure-3). The occurrence of another HaeIII restriction between nucleotide 556 and 749 is assumed, thus confirming the possible occurrence of 1-2 HaeIII restriction sites along the $1346 \mathrm{bp}$ of the MSTN fragment of Aceh cattle shown by the results of PCR-RFLP analysis. This is a novel finding which shows the specific number and locations of HaeIII restriction sites in the MSTN gene Aceh cattle.

Deeper analysis on the HaeIII restriction sites along bovine $M S T N$ was performed by comparing MSTN sequences of Bos Taurus Hereford (3147 bp, gene ID: 281187 ) and B. indicus (6686 bp, accession number AY794986), downloaded from GenBank database. The results showed the occurrence of 6 HaeIII restriction sites along the MSTN of B. taurus, which resulted in seven gene fragments after digestion, namely, 1622, 421, 404, 218, 215, 94, and $23 \mathrm{bp}$ [23]. The MSTN of B. indicus, interestingly, has nine HaeIII restriction sites, three of them in intron 1 ( 2 sites) and two that resulted in ten gene fragments after digestion. The result of sequence alignment analysis showed that Aceh cattle MSTN was aligned with the nucleotide (nt) $1-217$ of $B$. indicus MSTN and nt1 - nt501 of B. taurus MSTN sequences deposited in the GenBank (Figure-3a). The rest of the 1129 and 845 nucleotide sequences 
1st_BASE_3647693_P-AL_08_MSTN-R.seq Alignment to Myostatin gene_B indicus.str

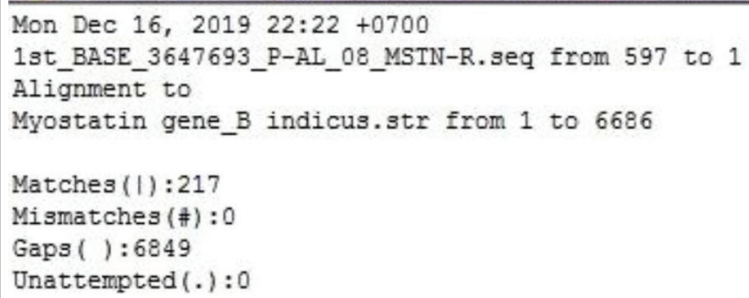

Figure-3: Sequence alignment of Aceh cattle myostatin (MSTN) gene fragment amplified using forward primer and Bos indicus MSTN gene (a) and Aceh cattle MSTN gene fragment amplified using reverse primer and $B$. indicus MSTN gene (b) (a) sequence alignment of MSTN gene B. indicus and Aceh cattle (b) Sequence alignment of MSTN gene Bos taurus and Aceh cattle.

of B. indicus and B. taurus MSTN, respectively, are located on the upper part of the sequences. There is no sequence available to make a comparison between the MSTN sequences amplified by forward primer. Altogether, the data presented in this study show that MSTN is highly variable in Indonesian beef cattle. This finding is in agreement with the condition found in several cattle, where five out of nine mutations identified in the MSTN are located in coding sequences [38]. The different size of DNA fragments, however, indicates possible species specificity of HaeIII restriction sites in cattle. Further PCR experiments to get enough DNA products for sequencing are now performed in our laboratory to provide better results and analysis.

The effect of the MSTN genotype on meat chemical parameters of Aceh cattle is presented in Table-5. The invariant genotype of FABP 4 found in Aceh cattle showed no possible effect of the gene in the chemical composition of the cattle meat, meaning it is not a potential marker for beef production in Aceh cattle. The data show meat moisture, ash, protein, fat, and cholesterol contents were not influenced by genotype during the current research trial. Although slight variation existed in meat chemical levels between cattle with the $\mathrm{AA}, \mathrm{AB}$, and $\mathrm{BB} M S T N$ genotypes, the differences were not significant $(\mathrm{p}>0.05)$. The potential effect of certain MSTN mutation on meat chemical content is shown by reduced external and internal intramuscular fat deposition in cattle carrying a single mutant allele from Belgian Blue or Piedmontese sire crossbreed compared to the pure breed [39]. These results suggest that selection for meat chemical parameters profile in Aceh cattle should be done not only based on MSTN/HaeIII variation but also other potential genes influencing meat composition such as calpain and calpastatin, the genes have been known and extensively studied their polymorphisms relationship with meat quality in cattle $[40,41]$. 


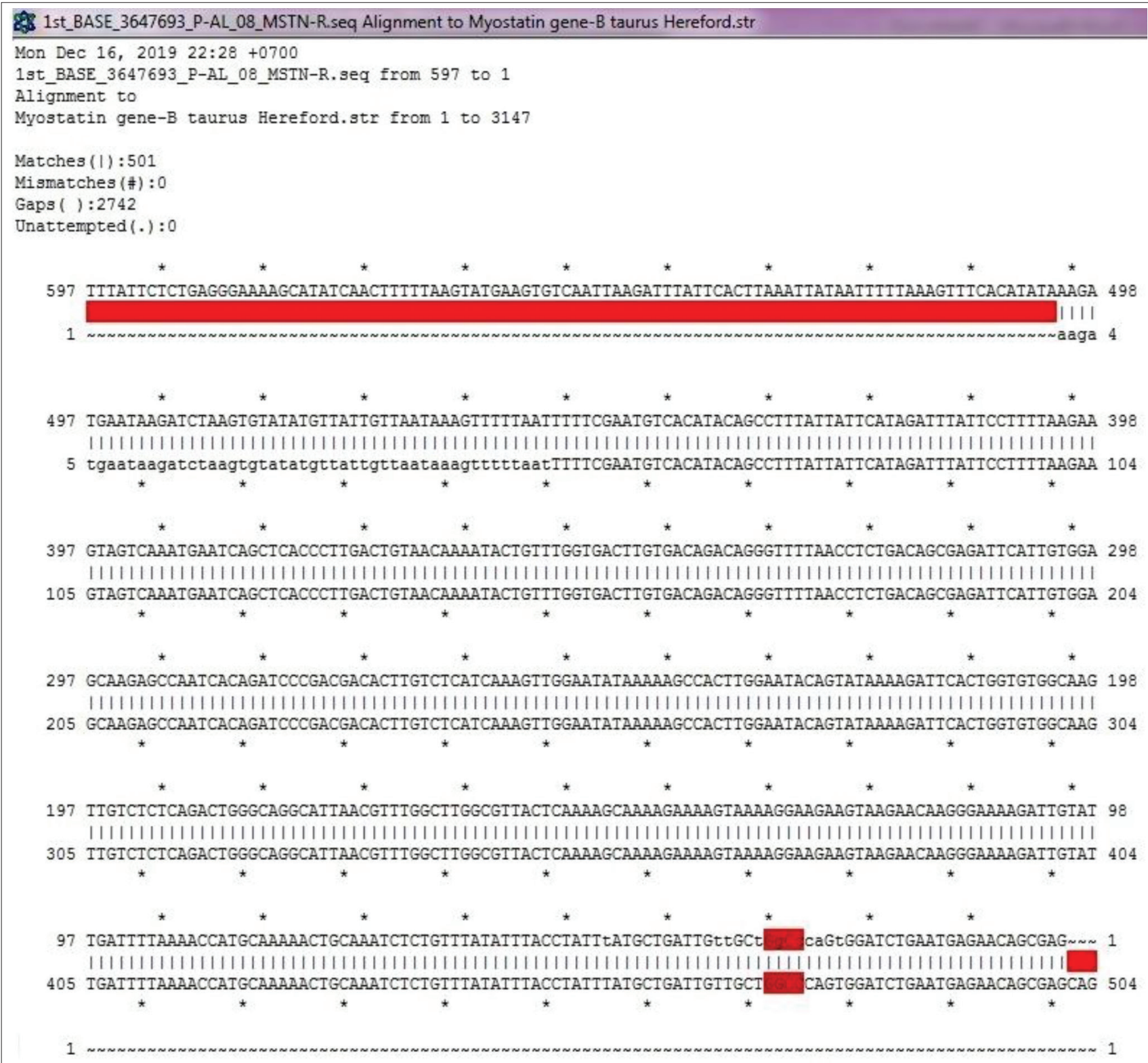

505 AAGGAAAATGTGGAAAAAGAGGGGCTGTGTAATGCATGITTGIGGAGGGAAAACACTACATCCTCAAGACTAGAAGCCATAAAAATCCAAATCCTCAGTA 604 Figure-3: (Continued).

\section{Conclusion}

The presence of different HaeIII restriction sites of MSTN gene, but not FABP4 gene, is responsible for the polymorphism of genes in Aceh cattle. The frequency of MSTN genotype agreed well with Hardy-Weinberg equilibrium, showing a balanced inheritance of the gene in the Aceh cattle population. The study showed that meat chemical parameters are influenced by breed but not by different commercial cuts and MSTN or FABP4 genotypes. This suggests that either MSTN or FABP4 is not a potential gene to be used for meat quality related-molecular assisted selective breeding in Aceh cattle.

\section{Authors' Contributions}

AA, MA, and MS designed and performed the experiments. MH and TSR extracted DNA from the samples and were responsible for PCR-RFLP analysis. MS and MH analyzed the data. AA, MA, and TSR wrote the manuscript. All authors read and approved the final manuscript.

\section{Acknowledgments}

This paper is supported by USAID through Sustainable Higher Education Research Alliance (SHERA) Program-Center for Collaborative Research Animal Biotechnology and Coral Reef Fisheries (CCR ANBIOCORE) No. 01/ANBIOCORE-FKH UNSYIAH/PK/II/2018. We also highly appreciate the Faculty of Veterinary Medicine of Universitas Syiah Kuala for equipment and facilities provided for the study, and the Head and Staffs of the Slaughterhouse of Banda Aceh for very kind support in Aceh cattle selection and meat sample collection. 


\section{Data Availability}

Supplementary data can be available from the corresponding author.

\section{Competing Interests} interests.

The authors declare that they have no competing

\section{Publisher's Note}

Veterinary World remains neutral with regard to jurisdictional claims in published institutional affiliation.

\section{References}

1. Singh, U., Deb, R., Alyethodi, R.R., Alex, R., Kumar, S., Chakraborty, S., Dharma, K. and Sharma, A. (2014) Molecular markers and their applications in cattle genetic research: A review. Biomarkers Genom. Med., 6(1): 49-58.

2. Koknaroglu, H., Loy, D.D., Wilson, D.E., Hoffman, M.P. and Lawrence, J.D. (2005) Factors affecting beef cattle performance and profitability. Prof. Anim. Sci., 21(4): 286-296.

3. Cushman, R.A., Miles, J.R., Rempel, L.A., McDaneld, T.G., Kuehn, L.A., Chitko-McKown, C.G., Nonneman, D. and Echternkamp, S.E. (2013) Identification of an ionotropic glutamate receptor AMPA1/GRIA1 polymorphism in crossbred beef cows differing in fertility. J. Anim. Sci., 91(6): 2640-2646.

4. Machado, M.A., Azevedo, A.L.S., Teodoro, R.L., Pires, M.A., Peixoto, M.G.C., de Freitas, C., Prata, M.C.A., Furlong, J., da Silva, M.V.G., Guimarães, S.E.F., Regitano, L.C.A., Coutinho, L.L., Gasparin, G. and Verneque, R.S. (2010) Genome wide scan for quantitative trait loci affecting tick resistance in cattle (Bos taurus $\times$ Bos indicus). BMC Genomics, 11(280): 1-11.

5. Hansen, P.J. (2004) Physiological and cellular adaptations of zebu cattle to thermal stress. Anim. Reprod. Sci., 82-83: 349-360. Doi:10.1016/j.anireprosci.2004.04.11.

6. Turner, J.W. (1980) Genetic and biological aspects of zebu adaptability. J. Anim. Sci., 50(6): 1201-1205.

7. Agrawal, V.K., Gahlot, G., Gupta, S., Yadav, S.P., Ashraf, M. and Thakur, S. (2017) Molecular characterization of myostatin gene affecting muscle growth in Kankrej cattle. Haryana Vet., 56(1): 25-28.

8. Carvalho, M.E., Eler, J.P., Bonin, M.N., Rezende, F.M., Biase, F.H., Meirelles, F.V., Regitano, L.C.A., Coutinho, L.L., Balieiro, J.C.C. and Ferraz, J.B.S. (2016) Genotypic and allelic frequencies of gene polymorphisms associated with meat tenderness in Nellore beef cattle. Genet. Mol. Res., 16(1): 1-15.

9. Crouse, D.J., Cundiff, V.L., Koch, M.R., Koohmaraie, M. and Seideman, C.S. (1989) Comparisons of Bos indicus and Bos taurus inheritance for carcass beef characteristics and meat palatability. J. Anim. Sci., 67(10): 2661-2668.

10. Ramsey, C.B., Cole, J.W., Bernadine, H.M. and Temple, R.S. (1963) Effects of type and breed of British, zebu and dairy cattle on production, palatability and composition. II. Palatability differences and cooking losses as determined by laboratory and family panels. J. Anim. Sci., 22(4): 1001-1008.

11. Chávez, A., Pérez, E., Rubio, M.S., Méndez, R.D., Delgado, E.J. and Díaz, D. (2012) Chemical composition and cooking properties of beef forequarter muscles of Mexican cattle from different genotypes. Meat Sci., 91(2): 160-116.

12. Ardicli, S., Dincel, D., Samli, H. and Balci, F. (2017) Effects of polymorphisms at LEP, CAST, CAPN1, GHR, $F A B P 4$ and DGAT1 genes on fattening performance and carcass traits in Simmental bulls. Arch. Anim. Breed., 60: 61-70.
13. Aiello, D., Patel, K. and Lasagna, E. (2018) The myostatin gene: An overview of mechanisms of action and its relevance to livestock animals. Anim. Gen., 49(6): 505-519.

14. Sellick, G.S., Pitchford, W.S., Morris, C.A., Cullen, N.G., Crawford, A.M., Raadsma, H.W. and Bottema, C.D.K. (2007) Effect of myostatin F94L on carcass yield in cattle. Anim. Genet., 38(5): 440-446.

15. Cho, S., Park, T.S., Yoon, D.H., Cheong, H.S., Namgoong, S., Park, B.L., Lee, H.W., Han, C.S., Kim, E.M., Cheon, I.C., Kim, H. and Shin, H.D. (2007) Identification of genetic polymorphisms in FABP3 and FABP4 and putative association with back fat thickness in Korean native cattle. $B M B$ Rep., 41(1): 29-34.

16. Shin, S.C., Heo, J.P., Chung, K.Y. and Chung, E.R. (2011) Validation of molecular diagnostic markers for carcass traits in commercial Hanwoo steers. $56^{\text {th }}$ International Congress of Meat Science and Technology(56 $6^{\text {th }}$ ICoMST), 15-20 August 2010, Jeju, Korea.

17. Imannulloh, I. (2012) Keragaman gen Miostatin (GDF-8) Pada Sapi Madura. In Departemen Biologi, Fakultas Matematika dan Ilmu Pengetahuan Alam. Institut Pertanian Bogor, Bogor.

18. Nugroho, H., Busono, W. and Maylinda, S. (2017) Polymorphisms of the Myostatin gene (MSTN) and its association with growth traits in Bali cattle. Indian J. Anim. Res., 51(1): 817-820.

19. Abdullah, M.A.N. 2008. Hubungan kekerabatan sapi aceh dengan menggunakan daerah displacement-loop (Relationship of aceh cattle using displacement-loop region). Agripet, 8(2): 91-14.

20. Abdullah, M.A.N., Noor, R.R., Martojo, H., Solihin, D.D., and Handiwirawan, E. (2007) The phenotypic variability of aceh cattle in Nanggroe Aceh Darussalam,. J. Indonesian Trop. Anim. Agric., 32: 11-21.

21. Indonesian National Standard. (2008) Quality of Carcass and Meat of Cattle. Agency, NS, Jakarta.

22. AOAC International. (2000) AOAC Official Method 994.10: Cholesterol in Foods. In: Official Methods of Analysis of the Association of Official Analytical Chemists. $17^{\text {th }}$ ed. Association of Official Analytical Chemists, Arlington, VA.

23. Azhar, A., Akmal, M., Hambal, M., Sabri, M., Rosa, T.S. and Santosa, S.F. (2019) Polymorphism of mysotatin gene in the local Aceh cattle. In: The $2^{\text {nd }}$ International Conference on Tropical Animal Science and Production (Tasp) 2019 and the $2^{\text {nd }}$ International CONFERENCE on Native Chicken (ICONC) 2019. Suranaree University of Technology, Nakhon Ratchasima, Thailand, p120-125.

24. Zhang, R.F., Chen, H., Lei, C.Z., Zhang, C.L., Lan, X.Y., Zhang, Y.D $>$, Zhang, H.J., Bao, B., Niu, H. and Wang, X.Z. (2007) Association between polymorphism of MSTN and MYF5 genes and growth traits in three Chinese cattle breeds. Asian-Aust. J. Anim. Sci., 20: 1798-1804.

25. Pedersen, D.K., Morel, S., Andersen, H.J. and Engelsen, S.B. (2003) Early prediction of water holding capacity in meat by multivariate vibrational spectroscopy. Meat Sci., 65(1): 581-592.

26. Agustina, K.K., Cahya, M.R.D., Widyantara, G.M., Swacita, I.B.N., Dharmayudha, A.A.G. and Rudyanto, M.D. (2017) Nutrition level and physical quality of Bali beef according to the sex and age of cattle. Bull. Vet. Udayana, 9(2): 156-163.

27. Wang, W.J., Wang, S.P., Gong, Y.S., Wang, J.Q. and Tan, Z.L. (2007) Effects of vitamin A supplementation on growth performance, carcass characteristics and beef quality in limousin $x$ luxi crossbreed steers fed a wheat straw based diet. Meat Sci., 77(4): 450-458.

28. Buckle, K.A., Edward, R.A., Fleet, G.H. and Wootton, M. (2007) Ilmu Pangan. UI-Press, Jakarta.

29. Manan, D. (2011) Peningkatan Potensi SDGH Sapi Aceh. Balai Pembibitan Ternak Unggul, Sapi Aceh Indrapuri, Aceh Besar.

30. de Almeida, J.C., Perassolo, M.S., Camargo, J.L., 
Bragagnolo, N. and Gross, J.L. (2006) Fatty acid composition and cholesterol content of beef and chicken meats in Southern Brazil. Rev. Bras. Cienc. Farm., 42(1): 109-117.

31. Khasrad, Sarbaini, Arfa'i and Rusdimansyah. (2017) Effect of cattle breeds on the meat quality of longissimus dorsi muscles. Pak. J. Nutr., 16(3): 164-167.

32. Onyango, C.A., Izumimoto, M. and Kutima, P.M. (1998) Comparison of some physical and chemical properties of selected game beefs. Meat Sci., 49(1): 117-125.

33. Rhee, M.S., Wheeler, T.L., Shackelford, S.D. and Koohmaraie, M. (2004) Variation in palatability and biochemical traits within and among eleven beef muscles. $J$. Anim. Sci., 82(2): 534-550.

34. Dunner, S., Miranda, E.M., Amigues, Y., Cañón, J., Georges, M., Hanset, R., Williams, J. and Menissier, J. (2003) Haplotype diversity of the myostatin gene among beef cattle breeds. Genet. Sel. Evol., 35(1): 103-118.

35. Sahin, S., Oner, Y. and Elmac, C. (2013) An investigation on gene regions related to some economic traits in Holstein and Brown Swiss cattle breeds by using PCR-RFLP technique. J. Agric. Sci., 19(3): 235-244.

36. Crisa, A., Marchitelli, C., Savarese, C.M. and Valentini, A. (2003) Sequence analysis of myostatin promotor in cattle. Cytogenet. Genome Res., 102(1-4): 48-52.
37. Aagaoglu, K.O., Akyüz, B., Kul, C.B., Bilgen, N. and Ertugrul, O. (2015) Genetic polymorphism of five genes associated with meat production traits in five cattle breeds in Turkey. Kafkas Univ. Vet. Fak. Derg., 21(4): 489-497.

38. Grobet, L., Poncelet, D., Royo, J.L., Brouwers, B., Pirottin, D., Michaux, H.C., Menissier, F., Zanotti, M., Dunner, S. and Georges, M. (1998) Molecular definition of an allelic series of mutations disrupting the myostatin function and causing double-muscling in cattle. Mamm. Genome, 9(3): 210-213.

39. Casas, E., Keele, W.J., Shackelford, D.S., Koohmaraie, M., Sonstegard, S.T., Smith, P.T., Kappes, M.S. and Stone, T.R. (1998) Association of the muscle hypertrophy locus with carcass traits in beef cattle. J. Anim. Sci., 76(2): 468-473.

40. Corva, P., Soria, L., Schor, A., Villarreal, E., Cenci, P.M. (2007) Association of CAPN1 and CAST gene polymorphisms with meat tenderness in Bos taurus beef cattle from Argentina. Genet. Mol. Biol., 30(4): 1064-1069.

41. Pinto, L.F., Ferraz, J.B., Meirelles, F.V., Eler, J.P., Rezende, F.M., Carvalho, M.E., Almeida, H.B. and Silva, R.C. (2010) Association of SNPs on CAPN1 and CAST genes with tenderness in Nellore cattle. Genet. Mol. Res., 9(3): 1431-1442.

\section{$* * * * * * * *$}

